\author{
(online) $=$ ISSN $2285-3642$ \\ ISSN-L = $2285-3642$ \\ Journal of Economic Development, Environment and People \\ Volume 5, Issue 1, 2016 \\ URL: http://jedep.spiruharet.ro \\ e-mail: office jedep@spiruharet.ro
}

\title{
Contributions to the Analysis of Amendments of the Crime Stipulated in Article 43 of Law no. 255/1998 on the Protection of New Varieties of Plants Made by Law no. 187/2012 for the Enforcement of Law no. 286/2009 on the Criminal Code ${ }^{1}$
}

\author{
PhD Bujorel Florea, Associate Professor ${ }^{2}$ \\ Attorney of the Bucharest Bar \\ ${ }^{2}$ Faculty of Legal, Political and Administrative Studies of Bucharest, "Spiru Haret" University
}

\begin{abstract}
The article brings into question the criminal protection of new varieties of plants. The author presents certain judicial norms, as previous issues, concerning the occurrence and protection of the rights over new varieties of plants through the granting of the variety patent. Furthermore, the study indicates the amendments made by Law no. 187/2012 on the enforcement of Law no. 286/2009 on the Criminal Code, concerning the counterfeiting crime incriminated in Law no. 255/1998 on the protection of new varieties of plants. Finally, the author underlines the specific elements of the contents of the investigated crime, thus providing the concerned parties with a table enabling, through the implementation thereof, the detection of the determining factors in the establishment and holding of the criminal liability of individuals infringing the rights of the plant variety patent holders, through counterfeiting.
\end{abstract}

Keywords: counterfeiting; variety patent; propagating material; manufactured and sold; day-fine system.

JEL Codes: $K 29$

\section{Introductory notions on the protection of new plant varieties}

The legal protection of the new plant varieties in Romania is provided by the provisions of Law no. $255 / 1998^{3}$ with further amendments and supplements.

\footnotetext{
${ }^{1}$ The article was previous presented at International Conference on Economic Sciences and Business Administration 2015

${ }^{2}$ E-mail address: floreabujorel@yahoo.com
} 


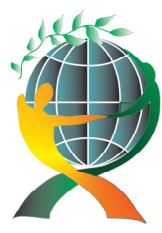

\author{
(online) $=$ ISSN $2285-3642$ \\ ISSN-L = $2285-3642$ \\ Journal of Economic Development, Environment and People \\ Volume 5, Issue 1, 2016 \\ URL: http://jedep.spiruharet.ro \\ e-mail: office jedep@spiruharet.ro
}

The law protects, acknowledges and defends the rights of the breeder on the new plant varieties belonging to all plant genera and species, on the Romanian territory, by granting a variety patent ${ }^{4}$.

The variety patent is granted by the State Institute for Variety Testing and Registration (ISTIS), the national authority for the performance of vegetation tests, a specialized body subordinated to the Ministry of Agriculture and Rural Development.

Within the meaning of the Law, a breeder is either the person creating or discovering and developing a new variety, or the person employing the abovementioned person or the person ordering the creation of new varieties.

Moreover, a breeder also includes the successor in rights of the abovementioned persons.

In order for the ISTIS to issue the variety patent, the variety shall meet certain patentability requirements, such as: novelty, distinctiveness, uniformity, stability and name.

Novelty is ensured by a variety that, on the registration date of the variety patent application or on the date of invoking the priority of the breeding or harvested material, was not sold or made available to third parties in any other way, by the breeder or with the consent thereof, for the commercial use of the new variety.

A variety meets the distinctiveness requirement if it clearly sets itself apart, through one or several relevant characteristics (resulting from a specific genotype or from a combination of genotypes), in relation to any other variety whose existence is notoriously known on the submission date of the patent application with the ISTIS (the State Institute for Variety Testing and Registration) or, as applicable, on the invoked priority date.

The uniformity of the variety is met if the plants subject to foreseeable variations during the breeding cycle remain sufficiently uniform in terms of their relevant characteristics, including the characteristics used to determine the distinctiveness of the soil, as well as in other characteristics used for the description of the variety.

Finally, a variety is stable if, following repeated breeding or in special cases, at the end of each breeding cycle, the relevant characteristics for the establishment of the distinctiveness or any other characteristics used to describe the variety remain unchanged.

\footnotetext{
${ }^{3}$ Law no. 255 of 30 December 1998 on the protection of new plant varieties was republished in the Official Gazette of Romania no. 926 of 28 December 2011. Brevitatis causa, any time we shall use the notion of Law in this study or any time we shall indicate any article of law without specifying the normative act it is part of, we shall refer to Law no. $255 / 1998$.

${ }^{4}$ Under the Law [see art. 2par. (1) letter a], variety refers to a group of plants belonging to a botanical taxon of the lowest known rank, that can be: 1) defined by the expression of the characters resulting from a specific genotype or from a specific combination of genotypes; 2) separate from any other group of plants, through the expression of at least one of the characters stipulated in section $1 ; 3$ ) deemed an entity in terms of its capacity to be bred as such.
} 


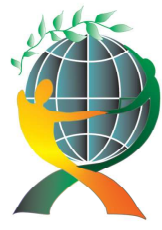

\author{
(online) $=$ ISSN $2285-3642$ \\ ISSN-L = $2285-3642$ \\ Journal of Economic Development, Environment and People \\ Volume 5, Issue 1, 2016 \\ URL: http://jedep.spiruharet.ro \\ e-mail: office jedep@spiruharet.ro
}

In order to be identified, the variety shall have a generic name. It shall vary from any other name indicating a variety belonging to the same plant species or to a species that is closely related to it.

The right over the variety patent is held by the breeder, the assignee ${ }^{5}$, the person developing the variety $^{6}$ or a different person holding the respective right together with the breeder ${ }^{7}$.

In accordance with art. 30 par. (1) of the Law, the variety patent holder shall benefit from the exclusive right to use the new variety and from the right to prohibit any person from performing the following actions concerning the propagating material or the harvested material belonging to the protected variety, without its authorization:

a) manufacture or reproduction;

b) conditioning during breeding;

c) offering for sale;

d) selling or any other form of trading;

e) import;

f) export;

g) storage for one of the cases stipulated under letters a)-f).

The variety patent applicant shall benefit from the same rights as the variety patent holder, as stipulated in art. 30 par. (1) of the Law, for the period starting on the publication date of the variety patent application (in the Official Gazette for the Protection of New Plant Varieties) and ending on the granting date of the variety patent ${ }^{8}$.

The variety protection duration ${ }^{9}$ is 25 years and it shall be calculated from the granting date of the variety patent to the end of the $25^{\text {th }}$ calendar year following the granting year. For varieties of fruit trees, trees and ornamental shrubs, vines, potatoes and hops, the protection term is 30 years and it shall be calculated from the granting date of the variety patent to the end of the $30^{\text {th }}$ calendar year following the granting year ${ }^{10}$.

In fact, unless the variety patent is granted on December $31^{\text {st }}$, in all other cases concerning the granting thereof, the protection duration shall exceed 25 years, respectively 30 years, and the difference consists of the period following the date when the respective period of years shall be met, to the end of the respective current year. For example, if the variety patent for vine is granted on 01 March 2000, and,

\footnotetext{
${ }^{5}$ See art. 10 par. (1) of the Law

${ }^{6}$ See art. 10 par. (3) of the Law.

${ }^{7}$ See art. 10 par. (4) of the Law.

${ }^{8}$ See art. 22 par. (1) of the Law.

${ }^{9}$ See art. 29 par. (1) of the Law.

${ }^{10}$ See art. 29 par. (2) of the Law.
} 


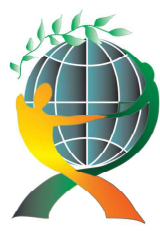

\author{
(online) $=$ ISSN $2285-3642$ \\ ISSN-L = $2285-3642$ \\ Journal of Economic Development, Environment and People \\ Volume 5, Issue 1, 2016 \\ URL: $\underline{\text { http://jedep.spiruharet.ro }}$ \\ e-mail: office jedep@spiruharet.ro
}

therefore, 30 years will have passed on 01 March 2030, the protection period shall be extended until 31 December 2030.

Considering the abovementioned ascertainment, we would like to propose, de lege ferenda, that the legal text regulating the variety protection term (art. 29) be restated, within the meaning that the variety protection period should be 25 , respectively 30 years, added to the time interval from the date when the respective period of years has been met, to the end of the respective current year.

In certain cases, explicitly stipulated by the Law, there is no infringement of the rights granted to the variety patent holder. This refers, for example, to cases where the variety is used for personal and noncommercial use, for experimental purposes, including the creation of new varieties from the initial material, for the creation, discovery and development of other varieties, the use of the variety in the period starting on the date when the holder is stripped of its rights and ending on the revalidation of the patent, on the exhaustion of the variety patent holder's rights, etc.

\title{
2. Amendments made to the crime consisting of the counterfeiting of new plant varieties
}

Art. 69 of law no. 187/2012 repealed art. 22 par. (3) and amended art. 43 of the Law no. 255/1998.

The repealed text (art. 22 par. (3)) concerned individuals that, during the interim protection period, committed, without the holder's authorization, the deeds stipulated in art. 30 par. (1) of the Law, equivalent to the committing of the crimes stipulated in art. 43 par. (1) and (2) of the Law.

The repeal of the incriminating text was required due to at least the following reasons:

- par. (3) of art. 22 was, in fact, a resumption of par. (2) of the same criminal law article; therefore, par. (2) of art. 22 regulates the duty of compensation, in accordance with the common law, of third parties infringing the rights stipulated in art. 30 par. (1), and the title for the payment of compensations shall be payable following the granting of the variety patent.

Therefore, had a final ruling been made to this extent, it would have been enforced on the criminal side, and it would only have been enforced on the civil side if the variety patent had been granted.

An unnatural event could have occurred, where a third party might have been criminally convicted and the decision might have been enforced, while the variety patent could have subsequently not been granted by the ISTIS.

In other words, it was possible for a third party to be criminally convicted for the infringement of certain rights of the variety patent application applicant, whereas the applicant had not benefitted from the respective rights, and therefore, for the infringement of non-existing rights. 


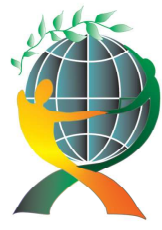

\author{
(online) $=$ ISSN $2285-3642$ \\ ISSN-L = $2285-3642$ \\ Journal of Economic Development, Environment and People \\ Volume 5, Issue 1, 2016 \\ URL: http://jedep.spiruharet.ro \\ e-mail: office jedep@spiruharet.ro
}

This is why we believe the legislator has deleted the deeds stipulated in art. 30 par. (1), committed by third parties, from falling under the incidence of criminal incrimination during the interim protection period.

- par. (3) of art. 22 of the law, repealed, contained an unenforceable requirement, i.e. the requirement for the deeds to have been committed "without the authorization of the holder". It referred to the variety patent holder, however, in the interim protection period, the respective person is not the holder of the variety patent, but the applicant of the patent, according to the contents of par. (1) of art. 22 of the Law, indisputably stipulating that "...the applicant shall temporarily benefit from the same rights granted to the variety patent holder, as stipulated in art. 30 par. (1)".

The rights of the variety patent holder occur on the patent granting date, and the applicant's rights, which are the same as those of the patent holder, stipulated in art. 30 par. (1), shall be valid starting with the publication date of the variety patent, up to the patent granting date.

Therefore, the requirement stipulated in the repealed legal text (par. (3) of art. 22) should refer to the committing of deeds "without the authorization of the variety patent applicant" and should in no case specify "without the authorization of the holder", as the latter shall only exist following the granting of the patent.

In terms of the actual amendments made to art. 43 of the Law, for easier identification thereof, in their analysis, we shall provide the text of art. 43 below, before and after the amendment.

Prior to the amendment, art. 43 read as follows:

"Art. 43". Counterfeiting and disclosure crimes

(1) A counterfeiting crime consists of the intentional performance, without the authorization of the variety patent holder, of any deed stipulated in art. 30 par. (1).

(2) Moreover, the intentional committing of the following deeds shall be deemed a crime:

a) the use of a name other than the registered name, for the propagating material that is manufactured and sold;

b) the use of a registered name of a new variety for the propagating material that is manufactured and sold, that does not belong to the respective variety;

c) the award, for the propagating material that is manufactured and sold, of a name that is very similar to the name of the protected variety, so as to cause confusion;

d) the sale of propagating material under the false statement that it belongs to the variety for which the variety patent was granted, thus misleading the buyer;

e) the forgery on the registration of a variety with the National Registry of Variety Patents; 


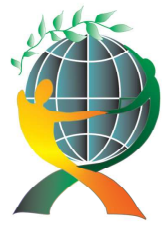

\author{
(online) $=$ ISSN $2285-3642$ \\ ISSN-L = 2285 - 3642 \\ Journal of Economic Development, Environment and People \\ Volume 5, Issue 1, 2016 \\ URL: http://jedep.spiruharet.ro \\ e-mail: office jedep@spiruharet.ro
}

f) drawing up false reports, as well as forging the documents required by this law;

g) the submission of documents containing false information.

(3) The deeds stipulated in par. (1) and (2) are punishable by imprisonment from 3 months to 2 years or by a fine from lei 10,000 to lei 30,000. The attempt is subject to sanction.

(4) The disclosure of data or information representing a trade secret concerning a new variety for which an application for the granting of a variety patent was submitted, shall be punishable by imprisonment from 6 months to 2 years or a fine from lei 10,000 to lei 30,000. The attempt is subject to sanction.

(5) If the crimes stipulated in par. (1), (2) and (4) are committed by a clerk exercising its work duties, the sanction shall consist of imprisonment from 6 months to 5 years. The criminal action shall be initiated on the prior complaint filed by the injured party.

(6) For prejudice caused to the patent holder, it shall be entitled to compensation, in accordance with the common law provisions, and it can request the court to rule the seizure or, as applicable, the destruction of the counterfeit products.

Following the amendment, art. 43 now reads as follows:

\title{
"Art. 43". Counterfeiting crimes
}

(1) A counterfeiting crime that is punishable by imprisonment from 3 months to 2 years or by a fine consists of the committing, without the authorization of the variety patent holder, of any deed stipulated in art. 30 par. (1).

(2) The sanction stipulated in par. (1) shall apply for the committing of the following deeds:

a) the use of a name other than the registered name for the propagating material that is manufactured and sold;

b) the use of the registered name of a new variety for the propagating material that is manufactured and sold, that does not belong to the respective variety;

c) the award, for the propagating material that is manufactured and sold, of a name that is very similar to the protected variety name, so as to cause confusion;

d) the sale of propagating material with the false mention that it belongs to the variety for which the variety patent was granted, thus misleading the buyer. 


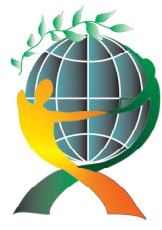

\author{
(online) $=$ ISSN $2285-3642$ \\ ISSN-L = $2285-3642$ \\ Journal of Economic Development, Environment and People \\ Volume 5, Issue 1, 2016 \\ URL: http://jedep.spiruharet.ro \\ e-mail: office jedep@spiruharet.ro
}

Having compared the contents of the two incriminating texts, of the amended prior article and of the text following the amendment, it can be concluded that the respective crimes have undergone the following amendments:

1) the rewording of the fine sanction in accordance with the day-fine system;

2) the deletion from the material element contents of the objective side of the counterfeiting crime concerning the actions incriminated in par. (2) letters e), f) and g), respectively: forgery on the registration of a variety with the National Registry of Variation Patents; the drawing up of false reports, as well as the forgery of the documents required by this law and the supply of documents containing false information;

3) the deletion of par. (3) of the incriminating text concerning the sanctions applicable for committing the incriminated deeds and the decriminalization of the attempt;

4) the deletion from the contents of the incriminating text of par. (4) concerning the crime consisting of the disclosure of data or information representing a commercial secret concerning a new variety for which an application was submitted for the granting of a variety patent;

5) the deletion of par. (5) of the incriminating text concerning the aggravated form when the counterfeiting and disclosure crimes regulated in par.(1), (2) and (4) were committed by a clerk exercising its work duties;

6) the deletion of par. (6) of art. 43 concerning the right of the patent holder to claim compensation for the damage caused to it, in accordance with the common law, and to request the court to rule the seizure or, as applicable, the destruction of the counterfeit products.

The first amendment of art. 43, respectively concerning the redrafting of the fine sanction, was established in order for the incriminating text to observe the provisions of the Criminal law in force, concerning the enforcement of the fine punishment in accordance with the day-fine system ${ }^{11}$.

In summary, in order to establish the total amount of the fine under the current system, the amount afferent to a day-fine, ranging between lei 10 and lei 500, shall be multiplied by the number of day-fines.

The special limits of the fine depend on the total amount of the imprisonment sanction stipulated by the special law. Therefore, based on the analyzed crimes, the special limits of day-fines range between 120 and 240 day-fines ${ }^{12}$, while the imprisonment sanction consists of no more than 2 years.

\footnotetext{
${ }^{11}$ See art. 61 of the Criminal Code.

${ }^{12}$ See art. 61 par. (4), letter b) of the Criminal Code.
} 


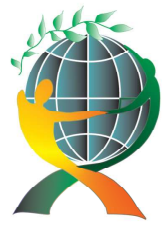

\author{
(online) $=$ ISSN $2285-3642$ \\ ISSN-L = $2285-3642$ \\ Journal of Economic Development, Environment and People \\ Volume 5, Issue 1, 2016 \\ URL: http://jedep.spiruharet.ro \\ e-mail: office jedep@spiruharet.ro
}

Based on such data, we can easily calculate the special limits of the total amount of the fine, in the analyzed case. They amount to lei 1200 (lei $10 \times 120$ day-fines) - the lower limit, and, respectively, lei 120,000 (lei $500+240$ day-fines) - the upper limit.

In terms of the second amendment consisting of the deletion from the material element of the objective part of certain alternative actions (the forgery on the registration of a variety with the National Registry of Variety Patents; the drawing up of false reports, as well as the forgery of the documents required by this law; the supply of documents containing false information), we believe the legislator has taken such a measure, as the abovementioned criminal actions are included in the contents of the crimes concerning forgery of documents incriminated by the Criminal Code ${ }^{13}$. Therefore, the interference of the same incriminations and of the difficulties concerning the legal classification and the criminal sanctioning of the respective deeds was deleted.

The third amendment, i.e. the deletion of par. (3) regulating sanctions applicable to the committing of the incriminated deeds and the attempt related to crimes concerning the counterfeiting of the plant variety, was required, as the applicable criminal sanctions are included in the current regulation in par. (1) of art. 43, as the incrimination was redrafted.

In terms of the deletion of the sanction for the attempt concerning the crimes consisting of the counterfeiting of the new plant variety, the measure that was taken falls under the general criminal conception of the legislator on the adoption of the current Criminal Code.

We believe that the fourth amendment consisting of the deletion of the incriminating text of par. (4) regulating the crime consisting of the destruction of data or information representing a trade secret concerning a variety for which an application was submitted for the granting of a variety patent, is fully justified.

We have no reserves concerning the deletion of the disclosure crime, as the Criminal Code incriminates a crime to which the legal classification of such deeds can relate ${ }^{14}$.

On the other hand, we cannot fail to notice that there is no difference of an unjustified sanctioning treatment between the disclosure deeds committed by the ISTIS staff, punishable in accordance with the Criminal Code, by imprisonment from 3 months to 3 years or by a fine ${ }^{15}$ and the disclosure actions of the data included in the patent applications committed by the State Office for Inventions and Trademarks (OSIM) staff, that are also punishable by imprisonment from 3 months to 3 years or by a fine ${ }^{16}$.

\footnotetext{
${ }^{13}$ See art. 320 ("Forgery of official documents"), art. 321 ("Intellectual forgery"), art. 323 ("Use of forgery") of the Criminal Code.

${ }^{14}$ See art. 304 ("The disclosure of secret work or non-public information") of the Criminal Code.

${ }^{15}$ See art. 304 par. (1) of the Criminal Code.

${ }^{16}$ See art. 62 of law no. 64/1991 on invention patents.
} 


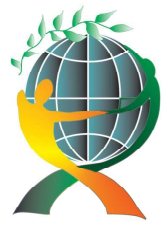

\author{
(online) $=$ ISSN $2285-3642$ \\ ISSN-L = $2285-3642$ \\ Journal of Economic Development, Environment and People \\ Volume 5, Issue 1, 2016 \\ URL: $\underline{\text { http://jedep.spiruharet.ro }}$ \\ e-mail: office jedep@spiruharet.ro
}

In relation to the abovementioned observations, we conclude that de lege ferenda, due to legal symmetry reasons, the disclosure crime by the OSIM staff, as well as by the persons carrying out works related to the inventions, of the data included in the patent applications, should also be deleted from the other special law, until the publication thereof (art. 64 par. (1)).

The fifth amendment of art. 43 concerns the deletion of par. (5) on the aggravated form of the counterfeiting and disclosure crimes regulated by par.(1), (2) and (4) when committed by a clerk exercising its work duties.

We conclude that the reason for the deletion of the aggravated form of the evoked crimes consists of at least the following reasons:

- first of all, as, even though par. (5) incriminated the aggravated form of the two crimes, the initiation of the criminal action was made on the prior complaint of the injured party, which is an institution that was not stipulated for the actual crimes, which irrationally lead to the situation where the provisions on the aggravated form were more favourable than the provisions incriminating simple crimes. In other words, there is a contradiction in the area of the aggravated form, between the more serious punishment applied to aggravated crimes (from 6 months to 5 years) compared to simple crimes (from 3 months to 2 years), on the one hand, and the more favourable provisions on the implementation of the criminal action, on the other hand.

Concerning the last aspect, even though we are in the aggravated form area, in the absence of a prior complain, the criminal liability of the clerk would have been removed, while any other infringer would have been held criminally liable. It would have been an unjustified difference of legal treatment in favour of the clerk exercising its work duties.

- second of all, the deletion of the aggravated form of the crime consisting of the disclosure of data or information was naturally established following the deletion of the simple crime stipulated in par. (4). The aggravated form could not have remained incriminated without the existence of the incrimination of the simple crime.

Lastly, the sixth amendment consists of the deletion of par. (6) concerning the right of the patent holder to claim compensation for the damage that was caused, in accordance with the common law provisions and to request the court to rule the seizure or, as applicable, the destruction of the counterfeit products.

The deletion of the incriminating text of the abovementioned provisions was required by the fact that they are included in the contents of the criminal procedure code in force ${ }^{17}$. The maintaining thereof would have led to the useless doubling of such provisions, in full disagreement with the actual orientation of the

${ }^{17}$ See art. 249 and art. 574 of the Criminal Procedure Code. 

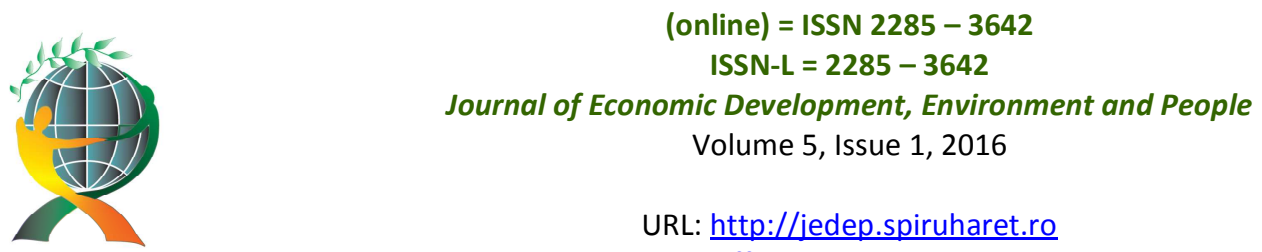

URL: $\underline{\text { http://jedep.spiruharet.ro }}$

e-mail: office jedep@spiruharet.ro

legislator and of the doctrine ${ }^{18}$ on the imperative requirement to simplify the legal institutions and norms, including on a criminal level.

\section{The elements specific to the crimes stipulated in the amended art. $\mathbf{4 3}$}

The legal subject of the crimes stipulated in art. 43 consists of the social relations formed around and due to the variety patent threatened by the counterfeiting deeds stipulated by law.

The material subject of the crime stipulated in par. (1) is the propagating material or/and the harvested material belonging to the protected variety against which the actions were directed, concerning manufacturing or reproduction, conditioning for breeding, offering for sale, sale or any other form of trade, import, export, as well as storage for one of the scopes stipulated in the previous actions.

Within the meaning of the Law ${ }^{19}$, propagating material refers to seeds, whole plants or various plant parts with the ability to breed whole plants.

The material subject of the crime stipulated in par. (2) is the entity against which the deeds are directed, concerning the use of a name other than the registered name, the use of the registered name of a variety that does not belong to the respective variety, the award of a name that is very similar to the name of the protected variety and the sale with the false mention that it belongs to the variety for which the variety patent was granted: the propagating material.

The active subject of the investigated crimes can be any natural or legal person that meets the general requirements stipulated in the Criminal Code for the committing of its criminal liability.

The passive subject of the current infractions is the variety patent holder or the variety patent applicant, on the period starting on the publication date of the patent application and ending on the granting date thereof.

The material element for the crime stipulated in par. (1) of art. 43 consists of the performance of any deed concerning the propagating material or the harvested material belonging to the protected variety stipulated in art. 30 par. (1), respectively: the manufacturing or reproduction, conditioning for breeding; offering for sale; selling or any other form of trading; import; export; storage for one of the scopes mentioned in the preceding paragraphs.

\footnotetext{
${ }^{18}$ See the "Acad. Andrei Rădulescu" Legal Investigation Institute of the Romanian Academy, "Simplification - an imperative of the modernization and improvement of the quality of law", scientific session, Bucharest - 17 April 2015, Universul Juridic Publishing House.

${ }^{19}$ See art. 2 par. (1) letter c) of the Law.
} 


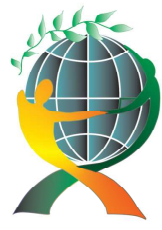

\author{
(online) $=$ ISSN $2285-3642$ \\ ISSN-L = 2285 - 3642 \\ Journal of Economic Development, Environment and People \\ Volume 5, Issue 1, 2016 \\ URL: http://jedep.spiruharet.ro \\ e-mail: office jedep@spiruharet.ro
}

For the counterfeiting crime in par. (2), the material element is any of the actions concerning the propagating material that is manufactured and sold: the use of a name other than a registered name for it; the use of the registered name of a new variety that does not belong to this variety; the award of a name that is very similar to the name of the protected variety, so as to cause confusion; the sale of propagating materials with the false mention that it belongs to the variety for which the variety patent was granted, thus misleading the buyer.

The immediate effect consists of the state of hazard created by any of the actions alternatively forming the material element of the objective side of the crimes stipulated by the analyzed text.

There is a causality relation between the actions establishing the material element of the crime and the immediate effect that theoretically results from the materiality of the deeds, where the causality relation performs the unity of the elements of the objective part.

Both for the counterfeiting crime stipulated in par. (1), and for the crime stipulated in par. (2) an essential condition is attached to the material element, for the existence of the crimes, i.e. that the incriminated deeds should be committed without the authorization of the variety patent holder.

The subjective part of the crimes stipulated in the two paragraphs implies the committing thereof with direct or indirect intention.

The committing of the crime occurs on the committing of any of the normative ways of carrying out the material element of the subjective side.

The sanction for committing the crimes is, as shown above, imprisonment from 3 months to 2 years or a fine.

\title{
4. Conclusions
}

The law on the protection of the new plant varieties is less studied in the legal doctrine, perhaps also due to the fact that it is not included in the analytical curriculum or in the course syllabus of the intellectual creation right in law schools. The general belief may be that law students and specialists continue to have more general knowledge in the area of intellectual property law, thus ignoring the fact that having general knowledge of the matter does not automatically lead to the adequate interpretation of the legal norms, but, in certain cases, to even less meanings. This is why we believe it is necessary to analyze the amendments and the contents of the crime on the forgery of new plant varieties, which we are certain will be of interest to specialists. The crimes falling under the investigated area have specific characteristics that can impact ethics in the specific universe where they are committed.

\section{References}




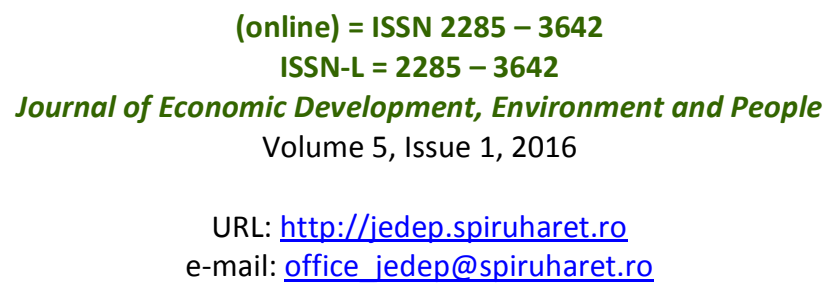

[1] Law no. 255 of 30 December 1998 on the protection of new plant varieties, republished in the Official Gazette of Romania no. 926 of 28 December 2011.

[2] V. Roș, Dreptul proprietății intelectuale - curs universitar, Global Lex Publishing, Bucharest, 2001.

[3] Joanaa Schmidt-Szalewski, Droit de la propriété industrielle, Dalloz, 1997.

[4] "Acad. Andrei Rădulescu" Legal Investigation Institute of the Romanian Academy, "Simplification - an imperative of the modernization and improvement of the quality of law", scientific session, Bucharest - 17 April 2015, Universul Juridic Publishing House.

[5] C-tin. Anechitoaie, Introducere în dreptul proprietății intelectuale, $6^{\text {th }}$ Edition, Bren Publishing, Bucharest, 2011. 